\title{
MODELS OF PERFORMANCES OF TRAVELLING VIRTUOSI IN THE PERIOD OF CLASSICISM: GIORNOVICHI IN STOCKHOLM
}

\section{VJERA KATALINIĆ}

\begin{abstract}
Giovanni Giornovichi/Ivan Jarnović (1747-1804), a famous violin virtuoso, performed in many European towns and aristocratic palaces, playing mostly his own concerti. The author analyses his sojourn in Stockholm in 1803. The models of his performances there have been investigated and related to concert performances which he gave in other European centres.
\end{abstract}

Key words: Ivan Jarnović / Giovanni Giornovichi; Stockholm; 18/19 $9^{\text {th }}$ century; concert performances.

Throughout the second half of the $18^{\text {th }}$ century, Stockholm experienced a significant development in all fields of science, culture and the arts, including music. It seems justified to call the period between 1770 and 1792, during the reign of King Gustav III Adolf (1746-1792), the "Gustavian Era”. The King was particularly adept at using opera and theatre for political purposes. His efforts to present himself as an enlightened ruler (possibly after the model of his uncle, the Prussian king Frederick the Great), and to present his country as one of the leading European powers, were correspondingly evident on the musical stage, in cherishing the examples of the French tradition, but also in cultivating a national theatre. The King himself was the author of texts and libretti for the theatre, as well as being a rich benefactor of the opera, which he directed towards contemporary European styles. He founded the Royal Music Academy (1771) and the Swedish Royal Opera (1773). There comic and serious musical stage works in Swedish were performed, composed by domestic and foreign (Italian and $\mathrm{German}^{3}$ ) authors who - attracted by the variety of opportunities - often

1 In texts on this virtuoso in English, I usually use the variant of his family name "Giornovichi", preferred in England of the late $18^{\text {th }}$ century as well as in some lexicographical sources. On the other hand, in Croatian texts I usually use the variant "Jarnović" mostly used in Croatian handbooks.

2 It can be found, for example, in the title of the article by Anna Johnson $(1989,327)$, where she marks the period of the cultural development as the "Gustavian Era".

3 Johann Gottlieb Naumann (1741-1801), Abbé Vogler (1749-1814) and some other composers were active there besides Kraus. 
settled down in Stockholm. Thus, the Swedish capital became a sort of a melting pot of various practices and styles. Gluck's reformed operas were especially well received, and became a model and a stylistic ideal of then popular works (Johnson, 1989, 334). The leading operatic composer became Joseph Martin Kraus (1756-1792), a German who settled in Stockholm in 1792 and remained there until the end of his life.

However, after several complots and, finally, a brutal assassination of the King in the Stockholm opera in 1792 (skilfully used and put into music by Giuseppe Verdi in the opera Un ballo in maschera), his son and heir to the throne, understandably, was not such a committed supporter of the opera as was his father. To the contrary, during the political turmoil and military clashes that followed the beginning of his ascension to the throne, the young King had more important duties than supporting music and theatre. For example, after frequent clashes, in 1809 Sweden lost its territory of Finland in favour of Russia, which provoked revolts, and the King was imprisoned and dethroned. This period was also marked by the rise of a bourgeois society, and of the foundation of cultural/ musical societies as specific models of bourgeois music making, thus replacing the sponsorship model of aristocratic society. During this turning point, a famous violinist Giovanni Giornovichi (Ivan Jarnović) arrived in the Swedish capital. A local newspaper - following the British model - announced him as "Maestro Giornovichi”.

This travelling virtuoso, famous and already well known from Paris to St Petersburg, had already put behind him thousands of miles and a series of successes, published compositions, and had experienced adventures of diverse kinds, having survived many accidents and various troubles that accompanied him on his tours. The majority of his public and private performances in France, the German-speaking countries, the Polish kingdom, Russia and Great Britain were well known owing to chroniclers and lexicographers who had followed his life-path since the late $18^{\text {th }}$ century. ${ }^{4}$ For a long time it was believed that he was born "in the waters of Ragusa", as written by his younger contemporary and acquaintance Adalbert Gyrowetz $(1848,10-11)$ and the place of his birth was understood as Dubrovnik, and not Ragusa / Sicily. Nevertheless, the documentation from Palermo, where he was baptised in 1747, seems to be the most reliable source, thus pointing to Sicilian Ragusa (even on a ship) as his probable birthplace. However, despite being familiar with a series of variants of his family name, his Croatian origin can be undoubted. In any case, his first musical training was in the Italian school, later supplemented by elements of

4 One of the first lexicographers who mentioned Giornovichi was E. L. Gerber: already in the first edition of his Historisch-biographisches Lexikon der Tonkünstler, i.e. during the lifetime of the violinist, he mentions him in two entries, as Jarnowick and as Giornovichi, where he wrote: "More on him see under his real name Jarnowich." (Gerber, 1790-92, 509) 
the French violinist tradition. His first recorded public performance in 1773, remarked upon and documented by newspaper reporters in Paris, launched him into the orbit of the outstanding virtuosos of the day, and in the same year, his first violin concerto was published there. After a decade of performances in France and Germany (but still with a base in Paris and - most likely - with a French passport), he started his tour of Berlin, Warsaw and St Petersburg, interrupting his voyage and staying in some lucrative centres sometimes as long as a year or two. Troubled by the riots on the eve of the 1789 Revolution, he left France and took a chance on the British Isles. As he arrived in London as an already renowned musician, he was invited to perform on various occasions in public and in the Royal Court in London, and on occasional visits to Edinburgh, Glasgow, Dublin and Bath in Somerset. It seems that the political situation in 1797, on the eve of the British-French conflict of 1798, prompted him to travel again. His touring on the Continent finally ended in St Petersburg, where he passed away on 23 November 1804.

Many biographers mentioned his sojourn in Stockholm, but without revealing any relevant sources. Giornovichi's concert pieces in print and manuscript form were preserved in Swedish libraries and collections (Tuksar, 1994, 231-236), but their owners could have collected them through orders; speaking of publishers, his music material could have been acquired mostly from Berlin and Amsterdam.

The usual routes towards the east, on the road towards the Russian capital of St Petersburg, were either by the sea (through German or Scandinavian ports), or by land (via Berlin, Warsaw, Minsk), depending on the season and meteorological conditions. During the first half of the 1780s, when Giornovichi travelled from Western Europe to St Petersburg and back towards central Europe, it is well known that he stopped in Berlin, Warsaw and Vienna; thus, it is less probable that on that occasion he also visited Stockholm. ${ }^{5}$ The first proof of his sojourn in Stockholm was discovered only recently, ${ }^{6}$ and here some of the results and new insights are presented.

According to data from the secondary sources, Giornovichi's name was first mentioned on the concert repertoire in Stockholm already from 1786 on, i.e. while he was still in pre-revolutionary France and later in England. Various local and visiting violinists performed his concerti, especially during the $1790 \mathrm{~s}$ (Vretblad, 1918). For example, the local newspaper Stockholms Posten announced

5 It was Mooser (1978a, 203) who stated that Giornovichi had visited Stockholm for the first time already in 1782-83, which has not yet been proved.

6 The research in libraries and collections in Stockholm and Uppsala was carried out in June 2015, within the European HERA project "Music Migrations in the Early Modern Age: the Meeting of the European East, West and South" (2013-2016). I am grateful to my Swedish colleagues Owe Ander (1956), Lars Berglund (1964) and Bertil van Boer (1952) for their suggestions and help. 
the concert of vocal and instrumental music on Sunday, 24 February 1793, to the benefit of Johann David Zander (ca. 1753-1796), the concert master of the Royal orchestra. Zander himself was to perform - as declared - "Czernowichi's violin concerto", as well as pieces by Joseph Haydn (1732-1809), Leopold Kozeluch (1747-1818), Ignaz Pleyel (1757-1831) and Kraus. The same musician had already played one of Giornovichi's concerti on 18 December 1789 in the Stockhlom Komedij-Teater (Vretblad, 1918, 237). Violinists like Johan Abraham Fischer (1744-1806), ${ }^{8}$ Ferdinand Gramm (?-1801), ${ }^{9}$ Johan Gottfrid Zaar (1754-1818), ${ }^{10}$ Carl Adam Norman $(1773-1812)^{11}$ and Paul Erasmus Chiewitz $(?-1815)^{12}$ performed his compositions as well. The most outstanding Swedish violinist who played his concerti in public on 14 October 1797 was Johan Fredrik Berwald (1787-1861) (Vretblad, 1918, 266-267), a child prodigy since he was 8. Later he accompanied his father on tour as far as St Petersburg (1803-1812), and after his return to Stockholm in 1812, he was employed as violinist in the Royal orchestra. ${ }^{13}$ Similar data have been found in Uppsala, where the violinists Westerdahl and Chiewitz (Jonsson, 1998, 109), ${ }^{14}$ played Giornovichi's concerti; in Åbo (today: Turku), the second largest (than still) Swedish city, the concert master Ferling of the Royal orchestra performed Giornovichi's concerto and one Rondeau by his (possible) teacher Antonio Lolli (1725-1802) on 4 March 1794.

The majority of Giornovichi's compositions preserved in Swedish collections was acquired from Hummel's printing offices in Amsterdam or Berlin, from the publishers Günther \& Böhme (Hamburg) and Jean André (Offenbach am Main), but a whole series of publications was brought from Paris, mostly published by Sieber.

However, until the end of the $18^{\text {th }}$ century, no traces of Giornovichi's activity in Sweden has been found. Nevertheless, during his sojourn in the Polish royal court in Warsaw in 1782, Giornovichi met the Count Otto-Magnus

7 Giornovichi's name has been found in the journals in various variants, mostly as Jarnovich, Giarnovichi, or Giornovichi (Stockholms Posten, 1793, 4).

8 Performance on 21 May 1786 (Vretblad, 1918, 237 / 229).

9 Performance on 5 January 1794 (Vretblad, 1918, 246).

${ }^{10}$ Performance on 15 January 1797 (Vretblad, 1918, 261).

${ }^{11}$ Performance on 5 February 1797 (Vretblad, 1918, 262).

12 Performance on 4 March 1797 (Vretblad, 1918, 263).

13 J. F. Berwald developed an outstanding career as composer and conductor in Stockholm, significantly influencing the musical life of the city.

${ }^{14}$ It was Carl Johan Westerdahl (violinist from 1796 to 1820 in the Royal ensemble, concert master, 1801-1820) who performed with Paul Chiewitz Sr. (violinist, 1782-1803) who probably performed the same concerti a year earlier in Stockholm (cf. note 11). Jonsson mentions the participation of the pianist Zetterberg (Jonsson, 1998, 236). 
von Stackelberg (1756-1800), ${ }^{15}$ who was Russian envoy in Poland, ${ }^{16}$ sent in 1791 to Sweden. Giornovichi undoubtedly recognised the importance of this influential diplomat and dedicated his 9th concerto to him. It might be that Stackelberg himself opened his path towards St Petersburg by giving him useful recommendations. In consequence, soon after his arrival in Russia, Giornovichi was hired for the private ensemble of virtuosos of the Empress Catherine.

It is not precisely known which route Giornovichi took on his way to Russia, although he probably went there via Minsk or Vilnius.

For his second trip to St Petersburg it seems that Giornovichi chose the maritime route. To be precise, after two especially successful concerts in the Berlin opera house in March 1802, when the Royal family applauded him (Schneider, 1978b, 187), the Copenhagen journals announced his concerts there already in October of the same year (Traerup, 1998, 13-26). ${ }^{17}$ He performed in the Royal theatre and at the court of Duke William Fredrik von Württemberg, the Governor of the city, and a week later also in the Frederiksberg castle, exclusively for the Royal family and their guests. After his departure on 18 December 1802 (Traerup, 1998, 19), the Danish journals continued to report occasionally on his tours and his life and success in Russia.

It was exactly on his way to St Petersburg that Giornovichi stopped in Stockholm. One of the dailies, Stockholms Posten, that regularly published notices on current cultural and musical events, published an announcement on 31 January (and reprinted it on 3 February) 1803, that:

"Mr. Giornovichi, who is already for three decades cherished and adored in Europe as a virtuoso of the first rank, sojourns in Stockholm and will soon be heard. Local music lovers asked Giornovichi to give a concert before his parting. He agreed, but asked if sufficient number of people in the audiences could be secured. Therefore, lists of subscribers have been established in the Rosenbad Society, Sållskapet Club in Kirstein House (Vasagattan 22) in Munkbron, Herrar Utters \& Comp. and in Silverstolpe bookstore. $\left.{ }^{[18}\right]$ As soon as the lists

15 This outstanding personality found his place in some representative historical surveys, as, for example, in the book Russian Portraits of the 18th and 19th Centuries (Mihajlovič, 1908, 142).

${ }^{16}$ Count Stackelberg, although originating from Westphalia, was one of the most outstanding Russian diplomats of that time, at the same time the éminence gris of the Kingdom of Poland (at that time under direct Russian protectorate).

${ }^{17}$ According to some news on renowned guests in the city, there is a note about Giornovichi who allegedly arrived from St Petersburg (Traerup, 1998, 14), which could not be true, because in the same year he - as mentioned already - performed in Berlin (Schneider, 1978b, 187). That is not an isolated example of the weak reliability of the reports of that time.

${ }^{18}$ These institutions listed here were not only the places for buying entrance tickets, but also, for example, subscriptions for journals, like Journal för Litteraturen och Theatern and some others. 
are completed, the entrance tickets, upon their payment, will be distributed to the gentlemen subscribers at the same places. All announcements on concerts will be given there, as well as in the newspapers." ${ }^{19}$

A few days later, it was reported that the subscription lists would be closed on 16 February, while on 1 and 2 March the same newspaper brought announcements of the beginning of Giornovichi's concert series:

"The admirers of Mr. Giornovichi announce with utmost pleasure that his concert will be given tomorrow, Wednesday, 2 March, in the great Knight hall, under the leadership of the Kapellmeister Haffner, and the following pieces will be presented: in the first part: 1) Haydn's symphony, 2) Mozart's aria, performed by Mr. Cellin, 3) Giornovichi's violin concerto performed by the composer, 4) Plane's sonata for harp with the accompaniment of the violin, performed by Miss Sophie Karsten, 5) Reichard's aria, performed by Mr. Karsten, the secretary of the Court. In the second part: 6) Lebrun's clarinet concerto, performed by Mr. Crusell, 7) Zingarelli's duet, sung by Mrs Karsten and Cellin, 8) Giornovichi's violin concerto, performed by the composer himself, and 9) Finale. The concert starts at 6 p.m." ${ }^{20}$

Giornovichi gave three concerts of that kind on 2, 11 and 27 March, with similar repertoire; ${ }^{21}$ unfortunately, according to the practice, more precise

${ }^{19}$ Herr Giornovichi, hwilken i Europa redan ett tredjedels Sekel kännes och beundras som en Virtuos af första rangen, är nu i Stockholm, och ärnar snart begifwa sig derhrån. Åtskillige Musikålskare hafwa anmodat Hr Giornovichi, att, innan sin bortresa, gifwa en Koncert, hwartill han samtyckt, endast han kunde försätras om ett tillräckligt antal åhörare. Att winna detta ändamål, har man inlemnat Subskriptionslistor på Societeten wid Rosenbad, Sällskapet I Kirsteinska Huset wid Munkbron, samt i Herrar Utters och Silverstolpes Boklådor. Så snart Subskriptionen är fulltecknad konna Herrar Subskribenter på nämde uttaga sina EntreBiljetter, mot erläggande af I R. stocket; hwarefter dagen till Koncertens gifwande, samt deß innehåll, stola i Tidningarne närmare tillkänna gifwas (Stockholms Posten, 1803a, 4; Stockholms Posten, 1803b, 4).

${ }^{20}$ Med Högwederbörligt tillstånd uppförer Herr Giornowichi Koncert uti Stora RiddarhusSalen, i dag Onsdag d. e Mars, under Kapellmästaren Haeffners anförande, hwarwid följande Pjeser gifwas: Första Afdelningen: 1) Sinfonie af Hajdn. 2) Aria af Mozart, sjunges af Hr Collin, 3) Concerto för Violin, af Giornowichi, spelas af honom sjelf. 4) Sonate för Harpa af Plane, med Violinaccompagnement, spelas af Mamsell Sophie Karsten. 5) Aria af Reichard, sjunges af Herr HofSekretararen Karsten. Andra Afdelningen: 6) Concerto för Klarinett af Lebrun, spelas af Herr Crusell. 7) Duo af Zingarelli, sjunges af Herrar Karsten och Collin. 8) Koncert för Violin af Giornowichi, spelas af honom sjelf. 9) Finale. Koncerten börjas Kl. 6 e. m. (Stockholms Posten, 1803c, 4; Stockholms Posten, 1803d, 4).

${ }^{21}$ Programme of the second concert in Giornovichi's series, on 11 March 1803: Symphonie Militaire by J. Haydn, Mozart's aria (Hr. Collin), Concerto for clarinet ... (Crusell, his own piece?), Paisiello's aria (Mamsell Viselius); Violin concerto Giornovichi, Mozart's aria with clarinet obligato (Hofsekretär Karsten, accompanied by Crusell), Concerto for flute, Viotti (arr.) (Hr. Brendter/Brendler), Finale. 
information on the pieces performed is lacking. The second concert was announced as a benefit for Mr. Crusell, a clarinettist from the first concert. ${ }^{22}$ The place of the performance - the great Knight hall - was one among usual places for secular concert events. This palace, erected already in the $17^{\text {th }}$ century, possessed a representative hall with coats of arms of the Swedish nobility (Vretblad, 1918, 8-10). Subscription benefit concerts were organised there almost every Sunday. Similar concerts were also organised in theatres (Royal theatre, Comedy theatre), and after the 1770s in the stock-exchange hall and in some restaurants and public parks as well (Vretblad, 1918, 10ff).

In any case, these few announcements in Swedish newspapers on Giornovichi's sojourn and activity in Stockholm seem to be quite modest, especially compared to his schedules in other European centres. It must be stated, that the journals in Stockholm are not rich in reports on cultural events, but were more oriented towards merchants, trade and legal issues. However, there is one letter that could explain and clarify an unusual situation: a letter directed on 18 March 1803 by Carl Gustaf Nordforss to Freiherr Niclas Edelcrantz (Mörner, 1972, 97-102), ${ }^{23}$ i.e. during Giornovichi's sojourn in that city. Nordforss (1763-1832) was an officer in the Swedish army, a writer, theatre director and translator of opera libretti. During 1790s, he was the second director of the Drama theatre, and between 1799 and 1818, director of the Opera. His task was to supervise the rehearsals, but he could have also influenced the repertoire. Nordforss was also translator of dramas, and wrote several of them as well. The addressee, Freiherr Niclas Edelcrantz (1754-1821, from 1789 known under the family name Clewberg), a Swedish born in Finland, was a poet and inventor, until 1783 the librarian at the Royal academy in Turku, when he moved to Stockholm and lead the Royal theatre. Later he was private secretary to King Gustav III Adolf, and in 1804 became the first director of Royal theatres and court orchestra; from 1805 he was the curator of the Royal museum, etc. ${ }^{24}$

Gustav IV Adolf, as mentioned earlier in this text, did not favour the opera and even wanted to dismiss it. On the other hand he wanted to help foreign musicians, especially the French ones who fled from the Revolution, to keep their jobs in the ensembles while, at the same time, the domestic ones were to some extend neglected, although often being better educated. When Giornovichi arrived in

Programme of the third concert on 27 March 1803: Symphony (without the name of the composer), Meyer's aria (Mr Collin), Violin concerto Giornovichi, Reichardt's aria (Herr Hofsekretär Karsten), Violin concerto Giornovichi, Finale.

22 The price of the ticket for this concert was 32 crowns, which was - in comparison with other concerts at that time - usual for such benefit performances in Stockholm.

${ }^{23}$ My thanks go to Owe Ander, who brought this letter to my attention.

${ }^{24}$ For the entry on Abraham Niklas Edelcrantz (Clewberg) see on: Svenskt biografiskt handlexikon, 2016a). 
Stockholm, the first director of the Opera was the Baron John Hugo Hamilton of Hageby (1752-1805). Nordforss describes in his letter the unhealthy situation among the musicians in the opera and guest performances of foreigners who additionally complicated already turbulent local relationships. Quarrels among local musicians occurred almost on a regular basis, as, for example, between the famous singer Cadet (about whom Nordforss had quite a bad opinion and often wrote negative reviews, but whom his admirers compared with the famous Italian castrato and singer Girolamo Crescentini) and the able Italian singer Garelli (sometimes written as Carelli; at that time active in the small theatre in the former arsenal, the Royal drama theatre). Giornovichi arrived amidst these battles for audiences and performed his own compositions, which were not suitable for just anybody. The person who felt especially endangered by his presence was Christian Friedrich Müller, ${ }^{25}$ the concertmaster of the opera orchestra, as well as his patron Baron Conrad Theodor von Schulzenheim (1768-1837). ${ }^{26}$ Nordforss mentioned in his letter the flautist Johann Franz Brendler (maestro di cappella 1802-1807) who was the father of the well-known composer Eduard Brendler (1800-1831). Nordforss describes that Stockholm at that time was the showplace of artists and charlatans of every kind. After his arrival in Stockholm, Giornovichi met Baron Hamilton (with whom he was allegedly acquainted from his Parisian years), who was furious about the local situation and told to the virtuoso: "Leave at once, go immediately to Russia, Sweden is not for you. Why did you come here at all without notifying me before? Leave at once. Tomorrow there is a caravan for Russia; I will connect you with some people to take you there immediately." (Mörner, 1972, 100) ${ }^{27}$ However, Giornovichi refused this suggestion and tried to meet Müller, because he wanted to organise his concert with the orchestra. Still, they did not meet because of some misunderstandings; Müller felt offended, did not want to hear about Giornovichi and turned the entire orchestra against the virtuoso. On the other hand, Giornovichi was upset at such groundless animosity and at first did not want to perform in public at all. Nevertheless, in the meantime, the famous Swedish singer Christoffer Christian Karsten ${ }^{28}$ took Giornovichi under his protection and, skilfully organising a few

${ }^{25}$ Christian Friedrich Müller (Rheinsberg, Brandenburg, 1752 - Stockholm, 1827) was one of the German composers active in Sweden. The pupil of Johann Peter Salomon, he started his violin tour in 1780. In Copenhagen he fell in love with a singer Caroline Walther (born Halle) and eloped with her to Stockholm; in the same year he became employed as a deputy concertmaster. From 1787 until his retirement in 1817 he was active as a concertmaster (see his bibliography on: Svenskt biografiskt handlexikon, 2016b).

${ }^{26}$ On the biography of the Lieutenant C. T. von Schulzenheim, see: Svenskt biografiskt lexikon, 2016 c.

${ }^{27}$ Nordforss and Giornovichi, communicated in French.

${ }^{28}$ Christoffer Christian Karsten (1756-1827) was reputed as one of the greatest opera singers in Swedish history. He earned the title of the Royal secretary in 1791. 
dinner parties and inviting the right persons, gradually humoured the orchestra members. Nordforss believed that Giornovichi was very talented in elegant communication in the society (although he was otherwise mostly well known for his quite rude manners and bad temper). Yet, at this occasion he was obviously so charming that he captivated the musicians and calmed down their revolt. It resulted in the three aforementioned concerts, announced in the press. In these performances included the participation of his protector Karsten as a singer and his daughter Sophie, ${ }^{29}$ the dancer, who also played the harp. The famous clarinettist Bernhard Henrik Crusell, an outstanding musician of Finnish origins (who also played at Giornovichi's concerts), arrived in Stockholm in 1791, and two years later became the first clarinettist of the Royal court orchestra, at the time when it was directed by Abbé Vogler, with whom he studied music theory and composition..$^{30}$ Besides Nordforss, it is possible that Giornovichi met some of these musicians earlier (for example, Crusell), elsewhere during his previous tours.

In any case, Giornovichi's sojourn in Stockholm lasted some three months, because already on 17 April 1803 he was announced in the St. Petersburgische Zeitung as a soloist in the local theatre: between the first and the second act of Paisiello's opera La serva padrona he was to play one of his concerti and a solo. During his stay in the Russian capital, the reviewers praised the virtuoso, saying that "he did not fail to keep pace with the Giornovichi of the previous 20 years" (Schneider, 1978b, 187), although already a new generation of violinists conquered this area with new techniques, styles and instruments (for instance, Pierre Rode).

During these three months in Stockholm, Giornovichi planned a series of subscriber concerts, usually organised by figures like Salomon in London and many others. One among them was usually the so-called benefit concert, because the entire income was assigned to one of the musicians - in this case, it was the clarinettist Crusell. Considering the complicated relations and the weak cultural life at large, it is not known whether Giornovichi performed in private as well; he was usually invited to play at royal courts in London, Berlin, Warsaw and elsewhere. Bearing in mind the winter season, the conditions for performing in open air were not suitable. ${ }^{31}$ As far as we know, there were no socalled "Zwischenakt" concerts organised with him in the opera, as the one in St Petersburg in the same year, and in many other places before. Giornovichi

${ }^{29}$ Karsten's daughter Sophie (with the Polish singer Sophie Stebnowska) became the first dancer in the Royal opera (1805-1806).

${ }^{30} \mathrm{He}$ also studied in Berlin and Paris, and was described as the best Finnish composer before Sibelius.

${ }^{31}$ Such promenade concerts were mostly organised in city parks, and the audience enjoyed them sitting around the stage, pavilion, or promenading around. 
himself, with the help of his friends and music lovers, organised his concerts, and the reaction and presence of the audiences seems to have been excellent. Thus, the undertaking was financially successful because he could obviously pay out the accompanying ensemble. On the contrary, that was not the case during his stay in Dublin in 1797, when his organisers (Dr. Cogan and the violinist Yaniewitz) cheated him. ${ }^{32}$ However, local intrigues in which he caught himself, probably prevented some more performances, but - on the other hand - enabled him to make a short stop during the cold season before starting for still cold Russia in April, when travelling might have been less complicated. Although already in advanced age - Giornovichi was at that time already 55 - he was still in perfect shape and able to cope with all difficulties of a musician on a free market where he acted quite skilfully. Still, he could have felt the change of the cultural climate and the twilight of the once successful Swedish musical life, and Hamilton's letter to Nordforss clearly testified to that transformation. Therefore, it was not at all unusual that the violinist rushed to St Petersburg, where the audiences still remembered him and received him with enthusiasm; opportunities for public performances were still numerous, although his influential protector - Catherine the Great - was no more. ${ }^{33}$ Yet, in Stockholm, there exists a souvenir that keeps Giornovichi's name still in memory: a mechanical clock that, among other compositions, reproduces the Russian theme from his 14 th concerto. ${ }^{34}$

\section{References}

Gerber, E. L., 1790-92. Historisch-biographisches Lexikon der Tonkünstler. Leipzig: Johann Gottlob Immanuel Breitkopf.

Gyrowetz, A., 1848. Biographie des Adalbert Gyrowetz. Vienna: Mechitaristen Buchdruckerei.

Johnson, A., 1989. Stockholm in the Gustavian Era. In: N. Zaslaw, ed. The Classical Era: From the 1740s to the End of the 18th Century. London: Palgrave Mcmillan. 327-349.

Jonsson, L., 1998. Offentlig music and Uppsala 1747-1854. Stockholm: Statens musikbibliotek.

32 On this case see more in: Katalinić, 2004, 21-30.

33 The Empress passed away in 1796, when her son Peter I ascended the throne; when he was murdered in 1801, his son Alexander I was installed in his place.

${ }^{34}$ Swedish clockmaker Pehr Strand constructed this mechanical clock at the end of the $18^{\text {th }}$ century; it is kept today in the Nydahl Collection in Stockholm. Besides the Russian rondo theme by Giornovichi, it reproduces abbreviated versions of compositions by Haydn, Mozart, Gluck, Pleyel and others. For that information, I am grateful to Göran Grahn, the curator of this collection. 
Katalinić, V., 2004. Ponovno o jedinom pismu “nepismenog” Jarnovića: koncerti u revolucionarnom Dublinu [On the letter by "illetré" Jarnowick revisited: concerts in revolutionary Dublin]. Arti musices, 35 (1), 21-30.

Mihajlovič, N. [Михайлович, N.], 1908. Ruskije portreti XVIII i XIX stoletii [Русские nортреты XVIII и XIX столетий], sv. IV. Sankt Peterburg: Ekspedicija zagotovlenija gosudarstvenih bumag.

Mooser, R.-A., 1950. Violonistes-compositeurs italiens en Russie au XVIIIe siècle. Giovanni-Mane Giornovicchi, dit Jarnowick. In: S. Tuksar, ed. 1978a. Ivan Mane Jarnović - hrvatski skladatelj. Zagreb-Osor: MIC-OGV. 201-208.

Mörner, C. G. S., 1972. Operkabaler - anno 1803. Ett opublicerat brev från C. G. Nordforss till A. N. Edelcrantz. Svensk tidskrift för musikforskning, 54, 95-102. Schneider, A., 1944. Ivan Mane Jarnović - A Croatian Violin Virtuoso and Composer of the 18th Century. In: S. Tuksar, ed. 1978b, Ivan Mane Jarnovića Croatian Composer. Zagreb-Osor: MIC-OGV. 127-192.

Stockholms Posten, 1793. [untitled] Spectakel. Stockholms Posten, 23 February, 4.

Stockholms Posten, 1803a. [untitled] Spectakel. Stockholms Posten, 31 January, 4. Stockholms Posten, 1803b. [untitled] Spectakel. Stockholms Posten, 3 February, 4.

Stockholms Posten, 1803c. [untitled] Spectakel. Stockholms Posten, 1 March, 4. Stockholms Posten, 1803d. [untitled] Spectakel. Stockholms Posten, 2 March, 4. Svenskt biografiskt handlexikon, 2016a, Abraham Niklas Edelcrantz (Clewberg). [online] Available at: <http://runeberg.org/sbh/a0264.html> [Accessed 10 June 2016].

Svenskt biografiskt lexikon, 2016b. Christian Friedrich Müller. [online] Available at: <https://sok.riksarkivet.se/Sbl/Presentation.aspx?id=8595> [Accessed 10 June 2016].

Svenskt biografiskt lexikon, 2016c. Conrad Theodor von Schulzenheim. [online] Available at: <https://sok.riksarkivet.se/Sbl/Presentation.aspx?id=6564> [Accessed 10 June 2016].

Trærup, B., 1998. Jarnović u Danskoj. Prva dokumentacija o koncertnim nastupima slavnog virtuoza Ivana Jarnovića u Danskoj 1802. godine [Giornovichi in Denmark. The first documentation on concert performances of the famous virtuoso Giovanni Giornovichi in Denmark in 1802]. Arti musices, 29 (1), 13-26.

Tuksar, S., 1994. Djela hrvatskih skladatelja 18. stoljeća u Kraljevini Švedskoj [Works by Croatian 18th-century composers in the Kingdom of Sweden]. Arti musices, 25 (1-2), 231-236.

Vretblad, P., 1918. Konsertlivet i Stockholm under 1700-talet. Stockholm: P.A. Norstedt \& Söners Förlag. 